\title{
Formation of the leaf surface area of spring wheat in various cultivation technologies
}

\author{
Galina Deriglazova ${ }^{1, *}$, Tatiana Gavrilova ${ }^{1}$ \\ ${ }^{1}$ FSBSI "Federal Agricultural Kursk Research Center" 70b, Karl Marx St., Kursk, 305021, Russia
}

\begin{abstract}
The article analyzes the research on the formation of the leaf surface area of spring wheat of Darya variety in different cultivation technologies on the chernozem soil of Kursk Region. The aim of the research was to study the peculiarities of the formation of the leaf surface of spring wheat depending on the cultivation technology and to identify the conjugate relationships of indicators under the conditions of chernozem soils of Kursk Region. The results of the conducted studies indicate that intensive cultivation technology contributes to the activation of the assimilation apparatus of leaves during the entire growing season of the crop. A high direct correlation between the leaf surface area in the Z 13 and Z 55 phases and the application of mineral fertilizers was established $(r=0.73 ; 0.80$, respectively). At $Z 25$ the leaf surface area has a direct noticeable relationship with primary tillage $(r=0.51)$ and a moderate one with the application of mineral fertilizers $(r=0.36)$. The use of sugar beet tops as organic fertilizer had a positive effect on the leaf area of one plant at Z 25 and Z 55, as evidenced by a noticeable correlation $(r=0.52$; 0.52 , respectively). It was found that the area of the flag leaf, as well as its length and width, increased with a decrease in the density of standing plants per square meter of cropped area. The flag leaf area and width decreased depending on the height of the plants, while the length increased. The development of the flag leaf area directly affected the accumulation of dry weight of plants $(r=0.53)$, the formation of the total assimilation surface of plants $(\mathrm{r}=0.72)$, as well as a high direct relationship with the length of the ear $(\mathrm{r}=0.75)$, which in turn is closely directly correlated with the weight of grain from one ear $(r=0.70)$. Thus, the evidence of the direct influence of the area of the flag leaf on the formation of the crop yield is presented.
\end{abstract}

Keywords: spring wheat, leaf surface area, flag sheet areas, cultivation technologies, related links, correlation relationship

\section{Introduction}

The yield of crops is formed due to the photosynthetic activity of plants. The leaf apparatus and its assimilation area have a big task - to form the main generative organ during the vegetation of plants - an ear filled with fullfledged grain $[1,2]$. Complex processes of plant growth and development in general depend on the size and absorption capacity of each cell of a green leaf to absorb the sun's energy in order to convert it into the energy for further growth and development of the plant as a whole [3-6].

The photosynthetic process occurring in the leaves, as well as in the stems and other green organs of plants synthesizes up to $90-95 \%$ of organic compounds in the cells $[5,7]$. About $80 \%$ of the produced wheat yield belongs to the leaves $[8,9]$.

The viability and active functioning of the leaf apparatus depends on the rate of development and the dynamics of formation of optimal leaf surface area [1, 2].

The size and spatial structure of the leaves determine the amount of energy absorbed by the crop, possible primary production of organic substances, and total transpiration [6]. In grain crops, the lower leaves of plants play an important role in the first stages of development, in the formation of the root system and the rudimentary ear. In the assimilation work of the plant during grain filling, the long-living leaves of the upper tiers (stem leaves) become crucial [10].

The number and size of leaves, the duration of their functioning, the value of the net productivity of photosynthesis directly affect the size of the accumulation of dry matter. Biological, natural and agronomical factors change the productivity of wheat, affecting primarily these indicators of photosynthesis [7].

A number of scientists argue that during grain filling, high leafiness can reduce the ability of plants to withstand high air temperatures and reduce the heat resistance of plants. In this regard, drought-resistant genotypes do not have a very high leaf area $[11,12]$.

A direct correlation was found between leaf area and weight of 1000 grains and grain content $(r=0.65-0.98 ; r$ $=0.32-0.96$ ) [8]. Other researchers do not observe such connections [12, 13]. Mathematical analysis shows a positive correlation between the yield and the leaf surface area, which ranged from a strong to an average value (from $r=0.95-0.98$ to $r=0.45-0.56$ ) $[8,10,11]$.

Thus, the analysis of scientific literature has shown that the issue of the development of the leaf surface of

* Corresponding author: g deriglazova $@$ mail.ru 
spring wheat and its impact on crop yield remains poorly studied and requires further research.

The aim of the work was to study the features of the formation of the leaf surface of spring wheat depending on the cultivation technology and to identify the conjugate relationships of indicators under the conditions of chernozem soils of Kursk Region.

\section{Materials and methods}

The research was carried out in the long-term field stationary experiment of the Laboratory of Technologies for Cultivation of Field Crops and Agroecological Assessment of Land in a 9-field crop rotation. Alternation of crops in the crop rotation was as follows: 1) clover, 2) winter wheat, 3) sugar beet, 4) spring wheat, 5) peas, 6) winter rye, 7) buckwheat, 8) oats, 9) barley + clover. A variety of spring soft wheat was Darya. The soil of the experimental plot was typical heavy-loamy chernozem. The replication of the experiment was three-fold. The location of the plots was systematic, the size of the sowing plot was $189 \mathrm{~m}^{2}$, the record area was $100 \mathrm{~m}^{2}$. The field work on the experimental plot was carried out in the best agronomical terms and, mainly, with the same machines and tools that are used under production conditions.

Table 1. Design of the experiment and the content of the variants.

\begin{tabular}{|c|c|c|c|c|c|c|c|}
\hline \multirow{3}{*}{ Variants } & \multirow{3}{*}{ Tillage } & \multicolumn{4}{|c|}{ Fertilizers } & \multirow{3}{*}{$\begin{array}{c}\text { Pestici } \\
\text { des }\end{array}$} & \multirow{3}{*}{$\begin{array}{c}\text { Biopr } \\
\text { eparat } \\
\text { ions }\end{array}$} \\
\hline & & \multirow[b]{2}{*}{ Mineral } & \multicolumn{3}{|c|}{ Organic } & & \\
\hline & & & Manure & $\begin{array}{c}\text { Sugar } \\
\text { beet } \\
\text { tops }\end{array}$ & $\begin{array}{l}\text { Green } \\
\text { manure }\end{array}$ & & \\
\hline \multicolumn{8}{|c|}{ Extensive technology } \\
\hline 1.Control & $\begin{array}{c}\text { Plowing } \\
20-22 \mathrm{~cm} \\
\text { deep }\end{array}$ & 0 & - & - & - & - & - \\
\hline $\begin{array}{l}2.50 \% \\
\text { provision with } \\
\text { min.fertilizers }\end{array}$ & $\begin{array}{c}\text { Plowing } \\
20-22 \mathrm{~cm} \\
\text { deep }\end{array}$ & $\begin{array}{c}\mathrm{N}_{30} \mathrm{P}_{30} \\
\mathrm{~K}_{30}\end{array}$ & - & + & - & + & - \\
\hline \multicolumn{8}{|c|}{ Intensive technology } \\
\hline $\begin{array}{l}3.100 \% \\
\text { provision with } \\
\text { min.fertilizers }\end{array}$ & $\begin{array}{c}\text { Plowing } \\
20-22 \mathrm{~cm} \\
\text { deep }\end{array}$ & $\begin{array}{c}\mathrm{N}_{60} \mathrm{P}_{60} \\
\mathrm{~K}_{60}\end{array}$ & - & + & - & + & - \\
\hline \multicolumn{8}{|c|}{ Biotechnology } \\
\hline $\begin{array}{l}\text { 6. } 100 \% \\
\text { provision with } \\
\text { org.fertilizers }\end{array}$ & \begin{tabular}{|c|} 
Subsurface \\
till. $20-22$ \\
cm deep
\end{tabular} & - & + & + & + & + & + \\
\hline $\begin{array}{l}7.100 \% \\
\text { provision with } \\
\text { org.fertilizers }\end{array}$ & \begin{tabular}{|c|} 
Subsurface \\
till. $20-22$ \\
cm deep \\
\end{tabular} & - & + & + & + & + & - \\
\hline $\begin{array}{l}8.100 \% \\
\text { provision with } \\
\text { org.fertilizers }\end{array}$ & \begin{tabular}{|c|} 
Plowing \\
$20-22 \mathrm{~cm}$ \\
deep
\end{tabular} & - & + & + & + & + & + \\
\hline $\begin{array}{l}\text { 9. } 100 \% \\
\text { provision with } \\
\text { org.fertilizers }\end{array}$ & $\begin{array}{c}\text { Plowing } \\
20-22 \mathrm{~cm} \\
\text { deep } \\
\end{array}$ & - & + & + & + & + & - \\
\hline \multicolumn{8}{|c|}{ Ecologic resource saving technology } \\
\hline $\begin{array}{l}13.50 \% \text { org./ } \\
50 \mathrm{~min} \text {. } \\
\text { fertilizers }\end{array}$ & $\begin{array}{l}\text { Surface } \\
\text { tillage }\end{array}$ & $\begin{array}{c}\mathrm{N}_{30} \mathrm{P}_{30} \\
\mathrm{~K}_{30}\end{array}$ & - & + & + & + & + \\
\hline $\begin{array}{l}14 . \\
50 \% \text { org. } / 50 \mathrm{mi} \\
\text { n. fertilizers }\end{array}$ & \begin{tabular}{|c|} 
Subsurface \\
till.20-22 \\
$\mathrm{cm}$ deep \\
\end{tabular} & $\begin{array}{c}\mathrm{N}_{30} \mathrm{P}_{30} \\
\mathrm{~K}_{30}\end{array}$ & - & + & + & + & + \\
\hline $\begin{array}{l}15 . \\
50 \% \text { org./50mi }\end{array}$ & \begin{tabular}{|c|} 
Plowing \\
$20-22 \mathrm{~cm}$ \\
\end{tabular} & $\begin{array}{c}\mathrm{N}_{30} \mathrm{P}_{30} \\
\mathrm{~K}_{30} \\
\end{array}$ & - & + & + & + & + \\
\hline
\end{tabular}

\begin{tabular}{|l|l|l|l|l|l|l|l|}
\hline n. fertilizers & deep & & & & & & \\
\hline
\end{tabular}

The phases of wheat development were established according to the International Classification (according to Zadox) [14].

The leaf area of spring wheat was determined by the method of measurements for grain crops [15]. Mathematical processing of the experimental data was carried out according to B.A. Dospekhov, statistical analysis of the data was carried out using the programs Microsoft Office Excel and STATGRAP.2_1. The conjugacy of the features was estimated using the nonparametric Spearman correlation coefficient. A qualitative assessment of the tightness of the relationship was carried out on the Cheddock scale.

\section{Results and Discussion}

The leaf area of both a single plant and the leaf surface area per hectare of spring wheat varied significantly under the influence of the studied technologies and development phases.

It was found that the leaf area of one spring wheat plant in the germination phase with the development of three leaves (phase Z 13), depending on the experimental variants, varied widely (from 3.92 to $8.27 \mathrm{~cm}^{2}$ ) (Fig. 1).

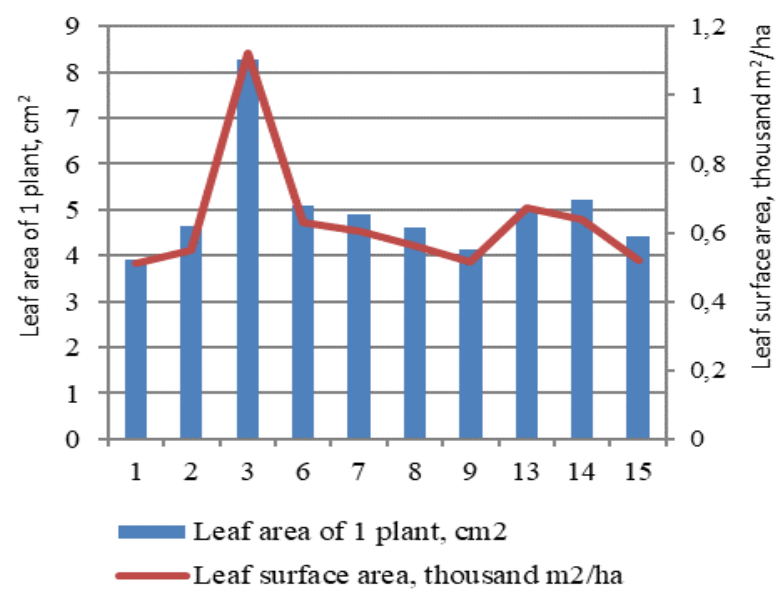

Fig 1. Leaf surface area of spring wheat in different cultivation technologies in phase Z 13

It changed significantly due to the applied fertilizers, which contributed to the activation of the growth functions of the leaves. Therefore, the area of the leaf surface of plants in the fertilized variants was formed in general faster than in the control. The greatest increase in the indicator in the experiment, in comparison with the control, was observed in the variant when cultivating over plowing using intensive technology with $100 \%$ availability of mineral fertilizers. In this variant, the indicator increased 1.1 times compared to the control.

The area of the leaf surface is directly related to the area of each leaf and the density of standing plants. A large area of wheat leaves was observed during intensive cultivation (1.2 times higher than the control variant). The leaves in this variant were distinguished by large length and width, and the crops were distinguished by high density of standing plants. In the other variants of 
the experiment the leaf surface area was $2-32 \%$ higher than in the control variant.

In the mid-tillering phase of the crop ( $\mathrm{Z} 25)$, the difference in the experimental variants in the area of the leaf surface was leveled (Fig. 2) and already varied to a lesser extent from 3.263 to 5.769 thousand $\mathrm{m}^{2} / \mathrm{ha}$. The increase in the fertilized variants of the experiment compared to the control was $9-77 \%$.

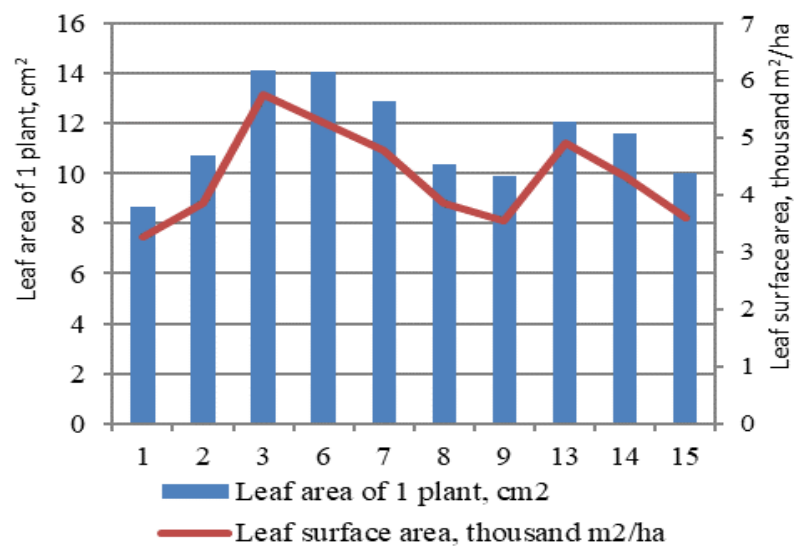

Fig 2. Leaf surface area of spring wheat in different cultivation technologies in the Z-25 phase

Analyzing the area of leaves from one plant in the mid-tillering phase of the crop, it can be noted that the highest value of the indicator was achieved not only in the third variant of the experiment, but also in the sixth one, which provides for subsurface tillage with $100 \%$ provision due to organic fertilizers with additional treatment with a biological preparation. The density of standing plants in this phase of development changed due to the bushiness of plants, which varied from 1.2 (in the control version) to 2.4 pcs. (in variants 3 and 13). Therefore, the superiority of the maximum leaf surface area was observed when intensive crop cultivation technology was used.

In the mid-heading phase (Z 55) maximum increase in the assimilation area of spring wheat occurred (Fig. $3)$.

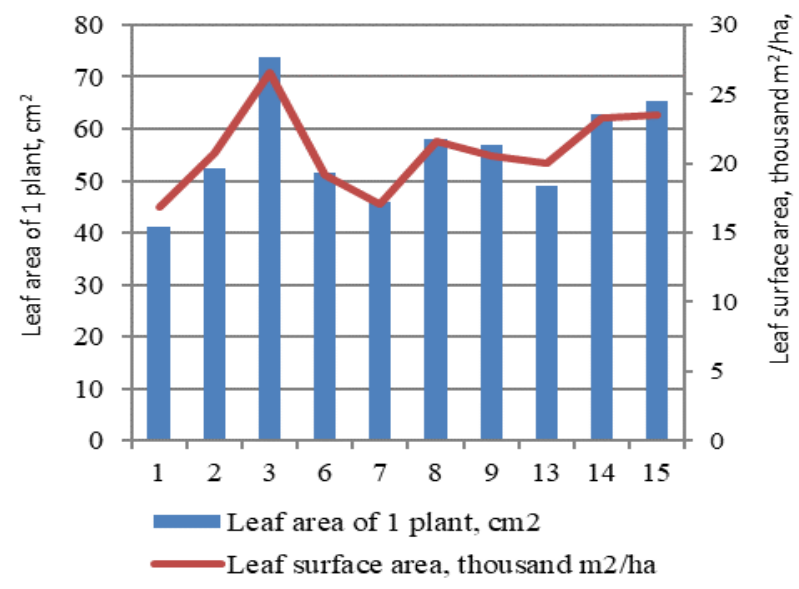

Fig 3. Leaf surface area of spring wheat in different cultivation technologies in the Z-55 phase.

The leaf area of one plant during the heading of spring wheat varied from 41.2 to $73.7 \mathrm{~cm}^{2}$. The increase due to fertilization was from 4.6 to $32.5 \mathrm{~cm}^{2}$, or $11-79 \%$. The third variant (intensive technology cultivation) was distinguished with the highest value of the indicator. Slightly lower were the indicators for resource-saving technology with plowing and subsurface tillage, which were lower than the most indicative result by 11.2 and $14.9 \%$.

Maximum leaf surface area during the growing season of the crop varied depending on the experimental variants from 16.830 to 26.535 thousand $\mathrm{m}^{2} / \mathrm{ha}$. An obvious advantage remained for the intensive technology of cultivation of spring wheat.

The analysis of the coupled data of the technology elements and the studied indicators revealed a high direct relationship between the leaf surface area and the application of mineral fertilizers during crop germination and heading ( $\mathrm{r}=0.73 ; 0.80$, respectively). When spring wheat tillering, the leaf surface area has a direct noticeable relationship with the change in the primary tillage $(r=0.51)$ and a moderate one with the application of mineral fertilizers $(r=0.36)$. The application of sugar beet tops had a positive effect on the leaf area of one plant during tillering and heading of the crop, as evidenced by a noticeable correlation $(\mathrm{r}=0.52 ; 0.52$, respectively).

A huge number of studies on the photosynthesis of wheat plants were conducted by V. A. Kumakov, who proved that the flag leaf has the highest photosynthetic activity compared to other assimilating organs [10]. Lyapshina Z. P. observed a direct relationship between the size of the total leaf area and the yield of biomass and grain [16].

In the conducted studies, the length of the flag leaf ranged from 16.8 to $21.4 \mathrm{~cm}$, and its surface area from 8.2 to $14.7 \mathrm{~cm}^{2}$ (Fig. 4).

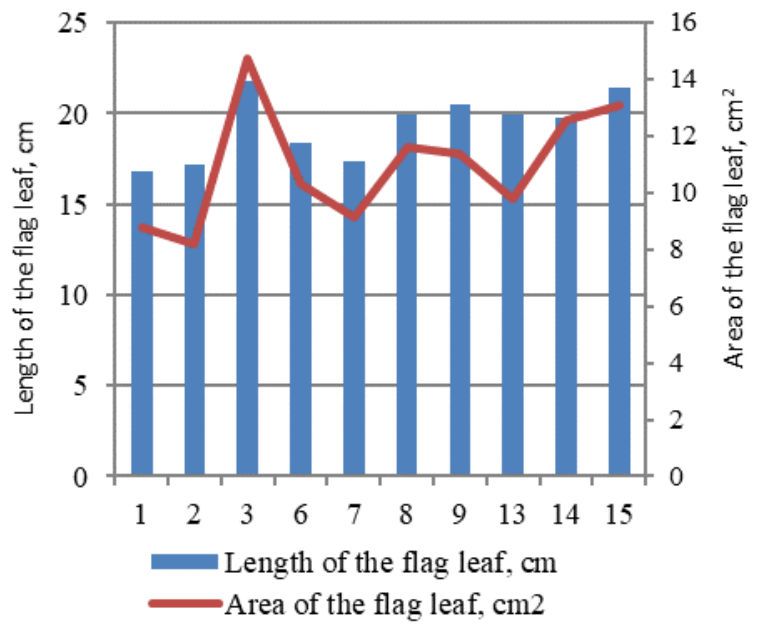

Fig. 4. Length and area of the flag leaf of spring wheat in various cultivation technologies.

Mathematical analysis of the conjugate data revealed the coefficients of pair correlation of the indicators presented in Table 2.

Table 2. Coefficients of pair correlation of spring wheat indicators. 


\begin{tabular}{|l|c|c|c|}
\hline \multicolumn{1}{|c|}{ Indicators } & Flag leaft are & $\begin{array}{c}\text { Length of the } \\
\text { flag leaf }\end{array}$ & Flag leaf width \\
\hline $\begin{array}{l}\text { Density of } \\
\text { standing plants }\end{array}$ & $\begin{array}{c}-0.78 \\
\text { (high } \\
\text { connection) }\end{array}$ & $\begin{array}{c}-0.63 \\
\text { (notable } \\
\text { connection) }\end{array}$ & $\begin{array}{c}-0.67 \\
\text { (notable } \\
\text { connection) }\end{array}$ \\
\hline Plant height & $\begin{array}{c}-0.57 \\
\text { (notable } \\
\text { connection) }\end{array}$ & $\begin{array}{c}0.53 \\
\text { (notable } \\
\text { connection) }\end{array}$ & $\begin{array}{c}-0.75 \\
\text { (high } \\
\text { connection) }\end{array}$ \\
\hline Ear length & $\begin{array}{c}0.75 \\
\text { (high } \\
\text { connection) }\end{array}$ & - & - \\
\hline
\end{tabular}

It was found that the area of the flag leaf, as well as its length and width, decreased with an increase in the density of standing plants per square meter of crop area. The flag leaf area and width decreased depending on the height of the plants, while the length increased.

The area of the flag leaf directly affected the accumulation of dry weight of plants $(r=0.53)$, the formation of the total assimilation surface of plants $(\mathrm{r}=$ 0.72 ), as well as a high direct relationship with the length of the ear $(r=0.75)$, which in turn was closely directly correlated with the weight of grain from one ear $(r=$ $0.70)$.

\section{Conclusion}

As a result of the research, it was found that the use of intensive technology of cultivation of spring wheat of Darya variety under the conditions of the chernozem soil of Kursk Region contributes to the activation of the assimilation apparatus of the leaves during the entire growing season of the crop.

A high direct correlation was established between the leaf surface area in the germination phase with the development of three leaves $(Z 13)$ and the middle of the heading of spring wheat ( $Z$ 55) with the application of mineral fertilizers $(r=0.73 ; 0.80$, respectively). In the middle of tillering of spring wheat ( $Z$ 25), the leaf surface area had a direct noticeable relationship with primary tillage $(r=0.51)$ and moderate with the application of mineral fertilizers $(r=0.36)$. The use of sugar beet tops as an organic fertilizer had a positive effect on the leaf area of one plant in the middle of tillering ( $Z$ 25) and middle of heading ( $Z$ 55) of the crop, as evidenced by a noticeable correlation $(\mathrm{r}=0.52 ; 0.52$, respectively).

It was found that the area of the flag leaf, as well as its length and width, increased with a decrease in the density of standing plants. The flag leaf area and width decreased depending on the height of the plants, while the length increased. The area of the flag leaf directly affected the accumulation of dry weight of plants $(r=$ $0.53)$, the formation of the total assimilation surface of plants $(r=0.72)$, as well as a high direct relationship with the length of the ear $(r=0.75)$, which in turn is closely directly correlated with the weight of grain from one ear $(r=0.70)$. Thus, the evidence of the direct influence of the area of the flag leaf on the formation of the crop yield is presented.
The work was carried out within the framework of the state task of Kursk Federal Agricultural Research Center on the topic No. 0632-2019-0010 "To develop scientifically substantiated parameters for building farming systems and agricultural technologies of a new generation in order to produce a given quantity and quality of agricultural products, preserve and reproduce soil fertility".

\section{References}

1. A. Nichiporovich, Photosynthesis and ways to improve the productivity of plants, Programming yields of crops, Chisinau, 2-4 (1974)

2. A. Balykin, L. Shashkarov, G. Mefodyev, V. Semenov, Bull. Nat. Acad. Sci. Republ, Kazakhstan 2, 384 (2020)

3. A. Nichiporovich, A. Stroganov, S. Chmura, M. Vlasov. Photosynthetic activity of plants in crops: Moscow, Publ. House ANSSR (1961)

4. V. Yakushev, E. Kanash, D. Rusakov, S. Blokhina Adv. Anim. Biosci., 8, 2 (2017)

5. A. Panfilova, M. Korkhova, V. Gamayunova, A. Drobitko, N. Nikonchuk, N. Markova, Res. J. Pharm., Biol. \& Chem. Sci. 10(2) (2019)

6. Fu-nian ZHAO, Shuang-xi ZHOU, Run-yuan WANG, Kai ZHANG, He-ling WANG, Qiang YU, J. Integr. Agr., 19, 9, (2020)

7. G. Goleva, T. Vaschenko, T. Kryukov, A. Golev, Bull. Voronezh State Agrar. Univ., 2(49) (2016)

8. A. Begishev, Trans. Inst. Plant Physiol. K. A. Timiryazev, 8, 1 (1983)

9. Shakeel Ahmad, Hakoomat Ali, Atiqueur Rehman, Rana Jahan Zeb Khan, Waqas Ahmad, Zartash Fatima, Ghulam Abbas, Muhammad Irfan, Hina Ali, Muhammad Azam Khan, and Mirza Hasanuzzaman, Pakistan J. Life \& Soc. Sci., 13(2) (2015)

10. S. Lyfenko, P. Dalnichuk, N. Erinyak, Physiological substantiation of models of wheat varieties, Moscow, Kolos (1985)

11. S. Lyfenko, Varietal differences of winter wheat leaf area unit and their relationship with the elements of productivity, in Trans. Reproductive process and the yield of field crops, Odessa (1981)

12. V. Maimistov, A. Kolesnikov, L. Bespalov Problems of winter wheat breeding for drought tolerance Breeding of winter wheat, in the Proceedings of the Scientific. Pract. Conference "Scientific heritage of Academician I. G. Kalinenko", Zernograd (2001)

13. F. Strizhova, L. Ozhogina, Bull. Altai State Agrar. Univ., 4 (20) (2005).

14. https://fishing-caravan.ru/sad-i-ogorod/fazy-razvitijapshenicy-po-zadoksu.html

15. N. Reshetsky et al., Plant physiology and biochemistry: method. Instructions, Gorki (2000)

16. Z. Lyapshina, Dependence of grain yield on the productivity of photosynthesis of spring wheat, in The most important problems of photosynthesis in crop production, Moscow (1970). 